\title{
Pengembangan Media Pembelajaran PAI Berbasis Macromedia Flash sebagai Sumber Belajar
}

\author{
Muh. Alif Kurniawan \\ Prodi Pendidikan Agama Islam, Fakultas Agama Islam, Universita Ahmad Dahlan Yogyakarta
}

\begin{tabular}{l}
\hline \hline Article Info \\
\hline Article history: \\
Received 2020-01-02 \\
Accepted 2020-04-06 \\
\hline
\end{tabular}

\section{Keywords:}

Development

Learning media

Macromedia flash

Learning resources

\begin{abstract}
The challenge of education in the era of the industrial revolution for educators is to develop a modern multimedia-based learning model. One opportunity for educators to realize this is the development of multimediabased learning media, one of which is macromedia flash. The development of media with macromedia flash can be used by educators in the learning process, both as a media presentation by teachers and interesting and interactive independent learning resources to increase the activeness and interest of students in learning so that learning is easily accepted as well as effective and efficient. This study aims to determine the quality of learning media based on macromedia flash PAI software that has been developed based on an assessment by media experts and material experts, as well as to determine students' responses to the learning media of Macromedia flash based PAI learning software. This type of research is a Research and Development (R\&D) learning media based on Macromedia flash PAI learning software. The data collection method uses observation, unstructured interviews, documentation and questionnaires (questionnaire) while the research approach uses a mix method, which is an approach that collects and analyzes data combining qualitative and quantitative research. The results of the assessment of the quality of learning media by media experts and material experts are included in both categories (B) with a percentage of ideals $83 \%$. Whereas the responses from students showed that this learning media received a very good response (SB) from students and deserved to be used as a source of learning for students with a percentage of $85.9 \%$.
\end{abstract}

This is an open access article under the CC BY-SA license.

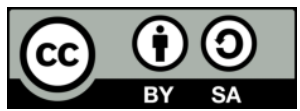

\section{Corresponding Author:}

Muh. Alif Kurniawan

Prodi Pendidikan Agama Islam, Fakultas Agama Islam

Universita Ahmad Dahlan Yogyakarta

E-mail: muh.kurniawan@pai.ac.id

\section{PENDAHULUAN}

Tantangan pendidikan di era revolusi industri bagi pendidik adalah dengan mengembangkan model pembelajaran modern berbasis multimedia. Di era revolusi industri 4.0 ini, paradigma pendidikan dari konvensional harus mulai berubah menjadi pendidikan yang modern, salah satunya adalah pembelajaran yang berbasis multimedia. Sehingga ini menjadi tantangan bagi semua pendidik masa kini, salah satunya adalah guru PAI (Zalik Nuryana, 2018). Pendekatan model lama sebenarnya lebih menimbulkan hal yang kurang baik dalam proses pembelajaran sehingga dampaknya menyulitkan peserta didik dalam proses menyerap ilmu pengetahuan. Sejak dulu sistem sekolah mengajarkan kepada anak untuk menghafal tanpa berfikir (Rusman, dkk., 2012: 2). Sehingga penting di era sekarang seorang pendidik untuk merealisasikan pendidikan modern.

Salah satu kesempatan pendidik untuk mewujudkan hal itu adalah pengembangan media pembelajaran berbasis multimedia. Pemanfataan media adalah penggunaan media secara sistematik dari 
sumber-sumber yang ditujukan bagi peserta didik. Proses penggunaan media adalah merupakan proses pengambilan keputusan (decision making) berdasarkan pada spesifikasi desain instruksional (Syamsu Arif dan Yanawati, 2018: 143). Salah satu tuntutan pendidikan dengan kemajuan teknologi dan pengetahuan berpengaruh terhadap proses pendidikan dan pengajaran, hal ini berakibat menuntut pendidik harus mampu menggunakan media (Asnawir \& Basyiruddin Usman, 2002: 4).

Secara bahasa kata media berasal dari bahasa latin yaitu medius yang memiliki arti pengatar, tengah, atau perantara. Sementara dalam bahasa Arab, media bermakna perantara (وسائل) atau pengantar pesan dari pengirim kepada penerima pesan (Azhar Arsyad, 2002). Media adalah perantara untuk menyalurkan pesan oleh pengirim untuk diterima oleh penerima pesan. Pengirim dan penerima pesan itu dalam dunia pendidikan adalah pendidik dan peserta didik, sedangkan media tersebut dapat berupa alat-alat peraga, buku, gambar, papan tulis dan lain sebagainya. Pada dasarnya posisi media sangat penting bagi dua posisi yang berbeda. Dengan menggunakan media pesan yang dikirimkan akan lebih mudah dipahami dan bahkan lebih efektif dan efisien (Harahap \& Siregar, 2018). Pengertian lain yang hampir senada media pembelajaran memiliki arti suatu pengantar pesan dalam proses belajar mengajar antara pemberi pesan yaitu pendidik kepada penerima pesan yaitu peserta didik (Sri Anitah, 2008: 1). Media pembelajaran juga diartikan sebuah alat yang berfungsi untuk menyampaikan pesan pembelajaran. Pembelajaran adalah proses interaksi antar peserta didik, pendidik dan materi ajar. Komunikasi tidak dapat berlangsung tanpa adanya peran sarana penyampai pesan atau perantara atau media (Ouda Teda Ena, 2001: 18).

Penelitian ini mengembangkan media pembelajaran dengan menggunakan media berbasis software Macromedia flash. Macromedia Flash adalah sebuah software yang harus dikuasai oleh para programer maupun desainer yang digunakan untuk merancang animasi untuk pembuatan presentasi bisnis maupun proses pembelajaran, halaman web, hingga pembuatan game pembelajaran interaktif serta manfaat lain yang lebih detail dan jelas (Dhani Yudhiantoro, 2006: 1). Macromedia flash termasuk software yang dapat dipakai untuk membuat sajian visual yang dapat menginterpretasikan berbagai media, seperti video, animasi, gambar dan suara. Software ini cukup populer untuk pembuatan berbagai macam aplikasi tutorial yang interaktif dan menarik.

Kelebihan macromedia flash adalah menarik minat peserta didik untuk belajar dikarenakan materi lebih indah sehingga ilmu yang disampaikan mudah dipahami. Peserta didik dapat menampilkan animasi berjalan sendiri dengan mengklik tombol play. Jadi, apa yang mereka bayangkan dapat dilihat secara visual (Nasir, 2009: 96). Dalam software ini juga terdapat actionscript yaitu bahasa pemrogaman yang digunakan untuk menganimasi objek, mengontrol navigasi, dan menginteraksikan objek dan movie (Heni A. Puspitosari, 2010: 7). Dari pengertian-pengertian tersebut dapat diambil kesimpulan bahwa macromedia flash merupakan suatu software desainer untuk membuat media pembelajaran interaktif yang memiliki fungsi penyaji materi pembelajaran lebih menarik sehingga lebih mudah dipahami oleh peserta didik.

\section{METODE}

Jenis penelitian ini adalah penelitian pengembangan atau Research and Development (R\&D) yaitu metode penelitian yang lakukan untuk menghasilkan suatu produk tertentu dan menilai keefektifan produk tersebut (Sugiyono, 2009: 407). Pengembangan atau Research and Development (R\&D) merupakan suatu proses pengembangan perangkat pembelajaran yang dilakukan melalui serangkaian riset yang menggunakan berbagai cara dalam suatu siklus yang melewati berbagai tahapan (Mohammad Ali \& Muhammad Asrori, 2014: 105), adapun tahapannya dalam penelitian ini sebagai berikut: Tahap 1 yaitu penilaian produk media pembelajaran berbasis software macromedia flash oleh ahli media dan ahli materi. Tahap 2 yaitu uji coba produk media pembelajaran berbasis software macromedia flash yang sudah dikembangkan dengan menggunakan instrument angket respon terhadap media tersebut.

Sedangkan menurut Borg and Gall ada sepuluh langkah prosedur penelitian pengembangan yaitu sebagai berikut: Penelitian \& Pengumpulan Informasi Awal/ Research and Information Collecting, Perencanaan/ Planning, Pengembangan Format Produk Awal/ Develop Preliminary Form of Product, Uji Coba Awal/ Preliminary Field Testing, Revisi Produk/ Main Product Revision, Uji Coba Lapangan/ Main Field Testing, Revisi Produk/ Operational Product Revision, Uji Coba Lapangan/ Operational Field Testing, Revisi Produk Akhir/ Final Product Revision, Desiminasi dan Implementasi/ Dissemination and Implementation (Zainal Arifin, 2012: 131). 



Adapun metode pengumpulan data dalam penelitian ini menggunakan metode observasi, wawancara tidak terstuktur, dokumentasi dan kuesioner (angket). Dengan tujuh tahap penelitian seperti yang di jelaskan pada gambar 1. Pendekatan dalam penelitian ini menggunakan pendekatan mix methode yang menurut Jhon. W Creswell sebagai sebuah metoda, mixed metodh research yaitu metode pengumpulan dan analisis data yang memadukan antara data kualitatif dan kuantitatif (Jhon Creswell, 2013: 5). Sedangkan teknik analisis datanya menggunakan analisis data deskriptif dengan menggunakan variabel penilaian kualitas media pembelajaran dan variabel respon siswa terhadap media pembelajaran. Data yang diperoleh kemudian dikumpulkan dan dianalisis.

\section{HASIL DAN PEMBAHASAN}

Variabel penilaian kualitas media pembelajaran PAI berbasis macromedia flash

Penilaian kualitas media pembelajaran didasarkan pada penilaian ahli media/ materi. Penilaian dilakukan dengan mengisi angket penilaian kualitas media pembelajaran yang disusun dengan skala likert (dibagi dalam lima skala) yaitu sangat baik (SB) dengan skor 5, baik (B) dengan skor 4, cukup (C) dengan skor 3, kurang $(\mathrm{K})$ dengan skor 2, dan sangat kurang $(\mathrm{K})$ dengan skor 1 dan terdiri dari 24 butir pernyataan yang terbagi dalam 6 aspek yaitu aspek kebenaran, keluasan dan kedalaman konsep; aspek kebahasaan; aspek keterlaksanaan; aspek tampilan; aspek suara; dan aspek kemudahan mengoperasikan. Data yang diperoleh kemudian dianalisis untuk menentukan kualitas media pembelajaran yang telah dikembangkan.

Setelah data terkumpul kemudian menghitung skor rata-rata setiap aspek yang dinilai dengan rumus:

$$
\begin{array}{ll}
\mathrm{X} & =\frac{\sum X}{\mathrm{~N}} \\
\mathrm{X} & =\text { Skor rata-rata tiap sub aspek kualitas } \\
\sum \mathrm{x} & =\text { Jumlah dari skor tiap sub aspek kualitas } \\
N & =\text { Jumlah penilai (Number of cases) (Anas Sudjiono, 2010: 81) }
\end{array}
$$

Hasil penilaian oleh ahli media dan ahli materi ditabulasi dan dianalisis untuk menentukan kualitas media pembelajaran PAI. Hasil penilaian dari tiap komponen aspek seperti yang telah dijabarkan di atas, kemuadian dijumlahkan untuk mengetahui skor nilai total akhir penilaian kualitas media pembelajaran oleh ahli media dan ahli materi sebagai berikut:

TABel. 1 Nilai AKHIR Media Pembelajaran Oleh lima Ahli

\begin{tabular}{cccc}
\hline No & Aspek & Rata-Rata & Kategori \\
\hline 1 & Kebenaran, keluasan dan kedalaman konsep & 25,4 & Sangat Baik (SB) \\
2 & Kebahasaan & 12 & Baik (B) \\
3 & Keterlaksanaan & 24,4 & Baik (B) \\
4 & Tampilan & 25,4 & Sangat Baik (SB) \\
5 & Suara & 8 & Baik (B) \\
6 & Kemudahan mengoperasikan & 4,4 & Sangat Baik (SB) \\
& Nilai CD media pembelajaran oleh 5 ahli & 99,6 & Baik (B) \\
\hline
\end{tabular}


Table 1. menjelaskan bahwa penilaian oleh ahli media dan ahli materi mendapatkan skor 99,6 dari skor maksimal 120. Maka hasil penilaian kualitas media pembelajaran oleh ahli media dan ahli materi termasuk kategori baik (B) dengan prosentase keidealan $83 \%$.

\section{Variabel respon siswa terhadap media pembelajaran PAI berbasis software macromedia flash}

Pemberian respon terhadap media pembelajaran ini dilakukan oleh 20 siswa SMP Negeri 2 Kalasan dengan cara mengisi lembar respon terhadap media pembelajaran yang telah disediakan. Penilaian lembar respon untuk siswa terdiri dari 10 butir pernyataan positif yang disusun dengan skala likert (dibagi dalam lima skala) yaitu sangat setuju (SS) dengan skor 5, setuju (S) dengan skor 4, tidak tahu (TT) dengan skor 3, tidak setuju (TS) dengan skor 2, dan sangat tidak setuju (STS) dengan skor 1. Untuk mengetahui tanggapan siswa terhadap media pembelajaran yang telah dikembangkan, digunakan angket yang disusun berdasarkan indikator struktur navigasi/ kemudahan mengoperasikan, tampilan, dan bahasa.

Data yang diperoleh kemudian dianalisa secara deskriptif kualitatif yaitu dilakukan perhitungan dengan rumus distribusi frekuensi relatif, yaitu:

$$
\mathrm{F}=\frac{F}{N} x 100 \%
$$

Keterangan:

$\mathrm{F}=$ Frekuensi yang sedang dicari presentasenya

$\mathrm{N}=$ Number of Cases (Jumlah frekuensi/ banyaknya individu)

$\mathrm{P}=$ Angka Presentase (Anas Sudjiono, 2010: 43)

Dalam rangka mengidentifikasi respon siswa terhadap media pembelajaran PAI berbasis software macromedia flash, peneliti menggunakan lima kategori yaitu: sangat baik, baik, cukup, kurang, dan sangat kurang. Pengidentifikasian yang dilakukan menggunakan ketentuan sebagai berikut:

$\begin{array}{lc}\text { Sangat baik } & : 81 \%-100 \% \\ \text { Baik } & : 61 \%-80 \% \\ \text { Cukup } & : 41 \%-60 \% \\ \text { Kurang } & : 21 \%-40 \% \\ \text { Sangat kurang } & : 0 \%-20 \% \text { (Suharsimi Arikonto, 1993: 56) }\end{array}$

Uji coba lapangan dilakukan terhadap 20 siswa SMP Negeri 2 Kalasan di ruang laboratorium komputer selama 2x40 menit. Selama belajar menggunakan media tersebut, siswa terlihat antusias dan memperhatikan dengan seksama tampilan yang tersedia. Soal-soal kuis dan evaluasi dikerjakan oleh siswa dengan sungguh-sungguh, bahkan terdapat beberapa siswa yang bersaing dengan temannya untuk mendapatkan nilai terbaik dan tercepat penyelesaian kuis atau soal latihannya. Sehingga dapat dikatakan bahwa siswa merasa senang belajar menggunakan media tersebut.

Pada kolom saran lembar respon siswa terhadap media pembelajaran yang telah dikembangkan tersebut, mayoritas siswa menyatakan bahwa tidak ada kekurangan yang perlu diperbaiki dari media tersebut. Tabel 2. Menjelaskan skor dari hasil jawaban siswa pada lembar respon.

Table I. Penilaian Siswa Terhadap Media Pembelajaran Pai

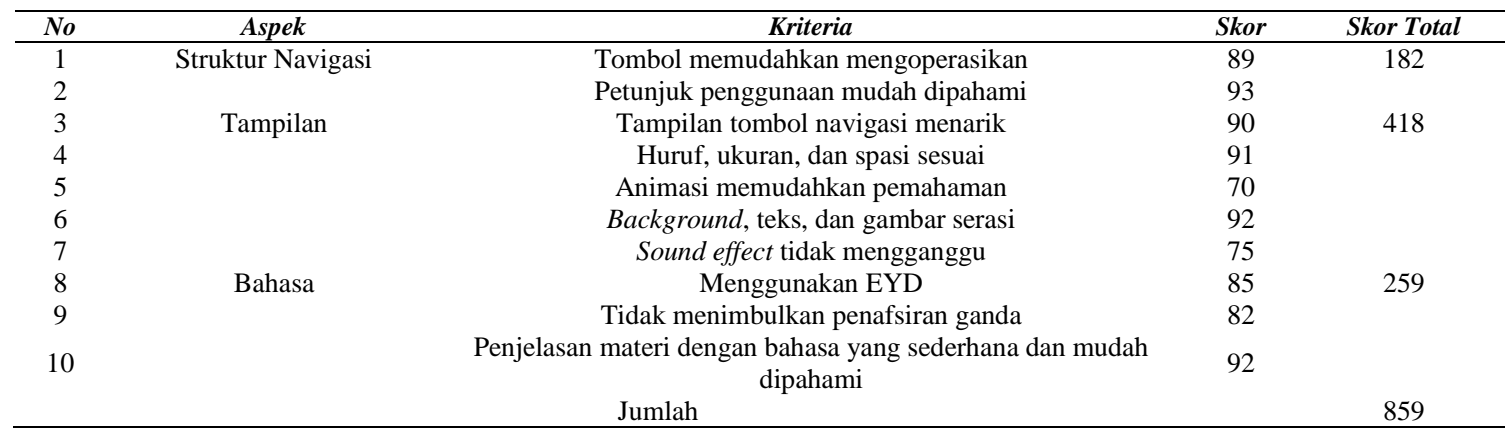

Hasil penilaian respon siswa berupa data kualitatif kemudian ditabulasi dan dianalisis untuk menentukan respon siswa terhadap media pembelajaran. Berdasarkan penilaian siswa terhadap media pembelajaran PAI yang telah dikembangkan, memperoleh skor akhir 859 dari skor maksimal 1000. Hal tersebut menunjukkan bahwa media pembelajaran ini mendapat respon yang sangat baik (SB) dari siswa dan layak untuk dijadikan sebagai sumber belajar bagi siswa dengan angka prosentase 85,9\%. 


\section{KESIMPULAN}

Berdasarkan hasil penelitian dan pengembangan yang telah dibahas di atas, maka dapat disimpulkan terkait pengembangan media pembelajaran PAI berbasis software macromedia flash dari ahli media dan ahli materi mendapat skor 99,6 dari skor maksimal 120, maka termasuk dalam kategori baik (B) dengan prosentase keidealan $83 \%$. Sedangkan hasil jawaban angket respon siswa terhadap media pembelajaran PAI berbasis software macromedia flash mendapat skor 859 dari skor maksimal 1000, dimana hal tersebut menunjukkan bahwa media pembelajaran mendapatkan respon yang sangat baik (SB) dengan angka prosentase $85,9 \%$ sehingga layak dijadikan sebagai sumber belajar.

\section{REFERENSI}

Anas Sudjiono. (2010). Pengantar Statistik Pendidikan. Jakarta: PT. Raja Grafindo Persada.

Asnawir \& Basyiruddin Usman. (2002). Media Pembelajaran. Jakarta: Ciputat Pers.

Azhar Arsyad. (2002). Media Pembelajaran. Jakarta: PT. Raja Grafindo Persada.

Dhani Yudhiantoro. (2006). Membuat Animasi WEB dengan Macromedia Flash Profesional 8. Yogyakarta: Andi Offset.

Harahap, M., \& Siregar, L. M. (2018). Mengembangkan Sumber dan Media Pembelajaran. Educational. https://doi.org/10.13140/RG.2.2.19282.86721

Heni A. Puspitosari. (2010). Membuat Presentasi Multimedia. Yogyakarta: Skripta Media Creative.

Jhon Creswell. (2013). Research Design: Pendekatan Kualitatif, Kuantitatif, dan Mixed (Ketiga). Yogyakarta: Pustaka Pelajar.

Mohammad Ali \& Muhammad Asrori. (2014). Metodologi dan Aplikasi Riset Pendidikan. Jakarta: PT. Bumi Aksara.

Nasir, M. (2009). PENGEMBANGAN KURIKULUM BERBASIS MADRASAH. HUNAFA: Jurnal Studia Islamika, 6(3), 273. https://doi.org/10.24239/jsi.v6i3.138.273-300

Ouda Teda Ena. (2001). Membuat Media Pembelajaran Interaktif dengan Piranti Lunak Presentasi. Yogyakarta: Indonesia Language and Culture Intensive Course Universitas Sanata Dharma.

Rusman, dkk. (2012). Pembelajaran Berbasis Teknologi Informasi dan Komunikasi. Jakarta: PT. Raja Grafindo Persada.

Sri Anitah. (2008). Media Pembelajaran. Surakarta: UNS Press.

Sugiyono. (2009). Metode Penelitian Pendidikan (Pendekatan Kuantitatif, Kualitatif, dan R\&D). Bandung: Alfabeta.

Suharsimi Arikonto. (1993). Prosedur Penelitian Suatu Pendekatan Praktik. Jakarta: PT. Rineka Cipta.

Syamsu Arif dan Yanawati. (2018). Pengantar Desain Pembelajaran (M. P. . Dr.Sumarto, ed.). Jambi: Pustaka Ma’arif Press.

Zainal Arifin. (2012). Model Penelitian dan Pengembangan. Bandung: PT. Remaja Rosdakarya.

Zalik Nuryana. (2018). Pemanfaatan Teknologi Informasi dalam Pendidikan Agama Islam. TAMADDUN, 19(1), 75-86. https://doi.org/http://dx.doi.org/10.30587/tamaddun.v0i0.818 